\title{
The Need Analysis of Guided Inquiry-Based Electronic Module Using Virtual Laboratory for Chemistry Learning
}

\author{
Cartika Candra Ledoh ${ }^{1, *}$ Sentot Budi Raharjo ${ }^{2,}$ Sulistyo Saputro ${ }^{3}$ \\ ${ }^{1}$ Master of Chemistry Education, Postgraduate School, Universitas Sebelas Maret, Indonesia \\ ${ }^{2}$ Department of Chemistry, Faculty of Mathematics and Natural Scinces, Universitas Sebelas Maret, Indonesia \\ ${ }^{3}$ Department of Chemistry Education, Faculty of Teacher Training and Education, Universitas Sebelas Maret, \\ Indonesia \\ *Corresponding author. Email: cartikacandraledoh1@student.uns.ac.id
}

\begin{abstract}
This study aims to analyze the need to develop an electronic module based on guided inquiry with the help of a virtual laboratory at Senior High School of 1 Pantai Baru, Rote Ndao Regency,NTT. This study used the survey method with Qualitative approach. This study used a random sampling technique for XI IPA class's students. The data was collected through interviewing chemistry teachers and distributing questionnaires to students. The instrument was developed under the supervision of two experts. The results showed that there were no teaching materials in chemistry learning. Teaching materials used in schools are still in printed form. Therefore, the learning session had not followed the development of the 21 st century globalization era yet. Innovative learning models were also rarely applied, and teachers only relied on lecture and discussion methods. Experimental learning was also rarely applied by teachers. Therefore, it can be concluded that the development of a guided inquiry-based electronic module with the help of a virtual laboratory needs to be applied so that students understand the concept of chemistry independently and experimental learning can be done virtually. The electronic module with the help of this virtual laboratory can be used whenever and wherever students want to practice in laboratory.
\end{abstract}

Keywords: Electronic module development, Guided inquiry, Virtual laboratory

\section{INTRODUCTION}

The 21st century learning demands a change from conventional teacher-centered learning to studentcentered learning. In this case, teachers have important roles to change learning patterns, where learning is an effort made by teachers deliberately to convey knowledge, organize, and create a learning environment with the help of various methods, so that students can carry out learning activities effectively, efficiently, and can get maximum results [1]. Based on the 21 st century national education paradigm, there are several competencies that students must master including: 1) critical thinking and problem solving: being able to think critically, laterally, and systematically, especially in science learning in the 2013 curriculum which emphasizes a scientific approach. The scientific approach includes activities to observe (observing), ask (questioning), reasoning (associating), trying (experimenting), and forming networks (networking) for all subjects. The learning approach that is appropriate and in line with the 2013 curriculum in the application of the guided inquiry learning model is a scientific approach. Guided inquiry learning model is a learning model which in its implementation requires active involvement of students with teacher guidance in solving a problem [2]. Its main objective is to develop students' attitudes and skills to solve problems independently $[3,4,5]$.

Electronic module is one of the learning media modified from conventional module which is integrated with the use of ICT. According to science education experts, learning can be made more attractive by applying ICT as a constructivist learning tool, [6] so as to increase motivation and stimulate student curiosity [7]. Learning science always involves the role of a laboratory [8,9]. In chemistry 
learning, laboratories can help students understand concepts, explain laws and theories through direct activities [10] experimental learning if carried out in a laboratory will contribute positively to students in understanding science, critical thinking, inquiry, discovery and problem-solving skills in Chemistry [11]. Limitations of tools, materials in a laboratory cause learning activities that involve laboratories to be rarely carried out resulting in less than optimal classroom learning processes so that in the learning process students do not get direct experience to find or prove chem theories and concepts. In addition, time management, large class sizes and also the amount of material that will be discussed in one meeting become a forum that often occurs in a practicum.

The electronic module using virtual laboratory developed will be integrated with the learning model so that it is easier for students to use. The electronic module will be equipped with various interesting learning activities according to the syntax in the learning model, so that it can encourage students to be active in learning. The learning model that will be integrated in the electronic module is a guided inquiry learning model. Guided inquiry learning model is a learning model to teach concepts and relationships between concepts. Smartphones are mobile devices that can be used for various multimedia such as computers, but smartphones have higher mobility and can be operated more effectively [12]. That way, the electronic module that is integrated with a virtual laboratory that can be operated via a smartphone will be more effective and will allow all students to use it even though they are not in school, where generally more students have smartphones than computers. Therefore, the researcher developed an electronic module based on guided inquiry with the help of a virtual laboratory that can be accessed anytime and anywhere as a solution to doing practicum due to limited tools and materials and the time it stops before completion.

The objective of this research is to produce an emodule reaction rate based on guided inquiry integrated virtual laboratory for practical SMA. EModule based reaction rate Guided inquiry integrated virtual laboratory can be used in the chemistry learning process in SMA / MA.

\section{RESEARCH METHODS}

This study was a development research or it is called as R \& D research that aimed to develop an electric module based on guide inquiry with the help of virtual laboratory on the reaction rate material. The Development has done by used procedural model and adapted the Electronic Development model by Borg and Gal. They were 1) data development research phase (to identify the problems) 2) designing phase 3) product development phase 4) dissemination phase. This study was the activity on the data development phase (identify the problems) including the analysis of needs in electronic module development. The method that used is descriptive qualitative method. The data collected from the questionnaires and interviews. The subject of this study was the chemistry teachers and 39 students of SMAN 1 Pantai baru that have learned the reaction rate material in Rote Ndao regency of East Nusa Tenggara. The data analyzed by interviewing the chemistry teachers, distributing the questionnaires about the analysis of student needs and doing observation to the students' test score on the reaction rate material.

\section{RESULTS}

Data obtained in this research were: 1) Data of students' need analysis, 2) teachers' need analysis based on the result of interview.

Table 1. Questionnaire of students' need analysis

\begin{tabular}{|l|l|l|l|}
\hline \multirow{2}{*}{ No. } & \multirow{2}{l}{ Questions } & \multicolumn{2}{l|}{ Choice of Answer } \\
\cline { 2 - 4 } 1 & $\begin{array}{l}\text { Teachers often use lecturing informatand discussion method in } \\
\text { teaching learning process. }\end{array}$ & 100 & 0 \\
\hline 2 & $\begin{array}{l}\text { Teacher have text books or other handouts in teaching about } \\
\text { Chemical concept. }\end{array}$ & 38.9 & 61.1 \\
\hline 3 & $\begin{array}{l}\text { I found difficulty in learning Chemical concept from the book. } \\
\text { (for example, due to the material completeness, format } \\
\text { explanation technique, etc.) }\end{array}$ & 85.5 & 14.5 \\
\hline 4 & In my opinion, Chemistry is a subject that is hard to learn. & 81.9 & 18.1 \\
\hline
\end{tabular}




\begin{tabular}{|c|c|c|c|}
\hline \multirow[b]{2}{*}{ No. } & \multirow[b]{2}{*}{ Questions } & \multicolumn{2}{|c|}{ Choice of Answer } \\
\hline & & Yes $(\%)$ & No(\%) \\
\hline 5 & $\begin{array}{l}\text { Teachers always conduct experiment/ practicum in Chemistry } \\
\text { subject, especially in the rate of reaction material. }\end{array}$ & 0.2 & 99.8 \\
\hline 6 & $\begin{array}{l}\text { Teachers use special teaching materials in teaching chemical } \\
\text { concept. (for example, module, worksheets, video, visual aids, } \\
\text { pictures, etc.) }\end{array}$ & 92.1 & 7.9 \\
\hline 7 & Language used in teaching material is understandable. & 37.2 & 62.8 \\
\hline 8 & $\begin{array}{l}\text { I need other learning materials, for example, electronic module } \\
\text { in which the material is related to daily life to help } \\
\text { understanding the material. }\end{array}$ & 89.3 & 10.7 \\
\hline 9 & $\begin{array}{l}\text { I have electronic devices (android smartphone) and sometimes } \\
\text { I bring it to school. }\end{array}$ & 93.8 & 6.2 \\
\hline 10 & $\begin{array}{l}\text { I agree with the teaching material development such as } \\
\text { interesting and understandable electronic module. }\end{array}$ & 85.5 & 14.5 \\
\hline
\end{tabular}

Table 2. Chemistry teachers' need analysis data

\begin{tabular}{|c|c|c|}
\hline No. & List of Questions & Teacher's Answers \\
\hline 1 & What method did you use to teach Chemistry? & $\begin{array}{l}\text { I mostly used lecturing method because it is } \\
\text { simple. I tried some other methods too, such } \\
\text { as group discussion and cooperative learning, } \\
\text { yet it didn't run well. }\end{array}$ \\
\hline 2 & $\begin{array}{l}\text { Did you use teaching material in teaching } \\
\text { Chemistry? }\end{array}$ & $\begin{array}{l}\text { I did. I used teaching material from a } \\
\text { publisher. }\end{array}$ \\
\hline 3 & $\begin{array}{l}\text { Have you ever made your own module and share it } \\
\text { to students in order to help them understand } \\
\text { chemical material? }\end{array}$ & $\begin{array}{l}\text { I haven't made my own module to chemical } \\
\text { hare to students because there are many } \\
\text { books in library for students }\end{array}$ \\
\hline 4 & Have you often used teaching media? & Sometimes I used picture as media. \\
\hline 5 & $\begin{array}{l}\text { Have you ever known about Guided-inquiry } \\
\text { learning model? If you have, did you apply it? }\end{array}$ & $\begin{array}{l}\text { I have. I know about it, but I have never used } \\
\text { it in my class. }\end{array}$ \\
\hline 6 & $\begin{array}{l}\text { Did you often hold practicum/ experiment activities } \\
\text { in Chemistry teaching learning process, especially in } \\
\text { reaction rate material. }\end{array}$ & $\begin{array}{l}\text { I rarely held experiment because tools and } \\
\text { materials at school are not provided, and the } \\
\text { time is limited, but practicum is actually an } \\
\text { effective way to deliver material to students. }\end{array}$ \\
\hline 7 & $\begin{array}{l}\text { Have you ever known about virtual laboratory? If } \\
\text { you have, did you apply it in experimental teaching } \\
\text { learning process? }\end{array}$ & No, I haven't. \\
\hline 8 & $\begin{array}{l}\text { Did you allow your students to use smartphone or } \\
\text { laptop in your class? }\end{array}$ & $\begin{array}{l}\text { I did, sometimes. It was used to search } \\
\text { information about assignment or exercise from } \\
\text { other references. }\end{array}$ \\
\hline
\end{tabular}




\begin{tabular}{|l|l|l|}
\hline No. & List of Questions & Teacher's Answers \\
\hline 9 & $\begin{array}{l}\text { Did school provide adequate computer for } \\
\text { students? }\end{array}$ & $\begin{array}{l}\text { It did. There are adequate computers used in } \\
\text { learning ICT. }\end{array}$ \\
\hline \multirow{3}{*}{10} & $\begin{array}{l}\text { Do you need teaching module collaborated with } \\
\text { conceptual virtual laboratory to teach Chemistry in } \\
\text { Reaction Rate material, such as guided inquiry- } \\
\text { based electronic module. }\end{array}$ & $\begin{array}{l}\text { I do. I think we need new innovations through } \\
\text { developing electronic module collaborated } \\
\text { with virtual laboratory that lead students to be } \\
\text { active, especially in reaction rate material. }\end{array}$ \\
\hline
\end{tabular}

\section{DISCUSSION}

Based on the results of the interviews, it is known that the teacher has used several methods during the learning process such as lectures and discussions. However, teachers have not implemented an innovative learning model. The use of the lecture method places students as listeners and recorders. This makes students have limited abilities at a low level. The weakness of the lecture method is that students only master the material provided by the teacher, while the teacher has difficulty ensuring student understanding. If the teacher has poor speaking skills, the lecture method will be very boring. Thus, it is natural that the chemical value has a low completeness test score. This is reinforced by the results of daily tests of chemical materials in the previous academic year, namely 2018/2019 with an average value of 67 . This is supported by the results of student questionnaires which state that chemistry is very difficult learning $81.9 \%$.

Learning in the classroom is also closely related to learning tools, and one of them is teaching materials. Based on the results of the interview, it is known that the teaching materials used by the teacher are textbooks from several publishers. The teacher has never made his own module and the textbooks used by the teacher contain complete material, but have not followed the syntax of a particular learning model that can facilitate students with various discovery activities. The textbooks used by teachers are still conventional (printed), and this is contrary to the $21 \mathrm{st}$ century which is identical with technological developments. Based on the results of the questionnaire, students said that $38.9 \%$ had chemistry textbooks. However, $85.5 \%$ of students had difficulty learning the chemical concepts in the book they owned. And from the results of interviews and questionnaire analysis, it is known that the media used by the teacher in the learning process is still conventional, such as pictures, and from the results of the questionnaire analysis it is known that $92.1 \%$ of students said that the teacher has never used technology-based learning media such as PPT.

Chemistry learning is closely related to experiments to find a concept. Experiments are part of the process aspect in the nature of science learning, where students are trained to carry out investigations by applying scientific methods that aim to explain a phenomenon, test the truth of a theory, or draw conclusions based on observed facts, but there is a gap between ideal conditions and facts. happens in the field. Based on the results of interviews with chemistry teachers, it was said that material related to experiments was rarely carried out, but every teacher believed that practicum learning was an effective delivery of material for students, because in addition to being able to train students' abilities, these activities could stimulate student effectiveness. This is also known from the results of the questionnaire analysis, where $99.8 \%$ of students stated that the teacher rarely invited students to do experiments, especially on the material on reaction rates. This is in accordance with Bruner's learning theory which states that students should do experiment independently in order to gain experience and new principles in knowledge. However, the obstacle experienced is the lack of time, tools and materials available to carry out practicum in a lesson so that practicum activities stop before completion and some materials do not do practicum due to limited tools and materials for practicum. Based on this, the researchers developed a virtual laboratory electronic media that can be accessed anytime and anywhere as a solution to doing practicum due to limited tools and materials and the time it stops before completion.

The use of a virtual laboratory allows students to learn more actively and be more enthusiastic because this media visualization is displayed attractively [13]. Virtual laboratories can make learning more interesting, interactive, and the quality of learning can be improved and the practicum process can be done anywhere and anytime [14], [15]. The use of virtual laboratories can increase student involvement in 
learning rather than activities carried out using blackboards and chalk in traditional classrooms [16].

Virtual laboratories can be used anywhere and anytime and can provide opportunities for students to actively study independently without the help [17]. Virtual laboratories have a positive influence on learning outcomes, learning becomes more interesting and interactive, can increase creativity, and problemsolving abilities [18] - [20]. The use of virtual laboratories allows students to learn more actively and be more enthusiastic because this media visualization is displayed attractively. On the other hand, virtual laboratories provide opportunities for students to experiment repeatedly until they really understand and at a time and place that is convenient for them. This virtual laboratory uses android which based on the results of the questionnaire $93.8 \%$ of students have androids which are usually bring to school.

The developed virtual laboratory is designed to integrate the guided inquiry model. The learning activities are designed according to the guided inquiry syntax. The guided inquiry model has been widely used in science learning and has shown a positive effect. Inquiry-based science education has a higher and positive effect on academic achievement, science process skills, and student attitudes towards science [21]. So that the electronic module based on guided inquiry combined with the virtual laboratory to be developed can be operated via a smartphone. This is because smartphones are one of the more popular information technologies among students and almost all students are supported by the results of a questionnaire which states that $83.8 \%$ of students have Androids.

\section{CONCLUSION}

Based on the result of the initial need analysis on the problems that exist in the school where researcher is, it become one of the reasons for doing an electronic module development by facilitating both students and teachers to understand the reaction rate material with the help of virtual laboratory, namely by conducting the experiment virtually (through interactive electronic media) without worrying about time consuming and the lack of tools and materials since this media can be accessed anytime and anywhere.

Thus, the research will be carried out to develop the alternative teaching materials, it is the development of an electronic module based on guided inquiry with the help of virtual laboratory on the reaction rate material.

\section{ACKNOWLEDGMENTS}

We would also like to show our gratitude to the School Principals in Rote Island for their help during the course of this research and all colleagues for their support and motivation.

\section{REFERENCES}

[1] A.F. Wittig, Theory and Problems of Introduction to Psychology Second Edition, Schaum's Outline Series, McGraw-Hill, 2001.

[2] C.C. Kuhlthau, L.K. Maniotes, A.K. Caspari, Guided Inquiry Learning in The 21st Century, Libraries Unlimited, 2007.

[3] T. Cofman, Engaging Students through InquiryOriented Learning and Technology, Rowman \& Littlefield Education, 2009.

[4] C.J. Conway, Effects of Guided Inquiry Versus Lecture Instruction on Final Grade Distribution in A One-Semester Organic and Biochemistry Course, Journal of Chemistry Education 91(4) (2014) 480-483. DOI: https://doi.org/10.1021/ed300137z

A. Chase, D. Pakhira, M. Stains, Implementing Process-Oriented, Guided Inquiry Learning for The First Time: Adaptations and Short-Term Impacts on Students' Attitude and Performance, Journal of Chemical Education 90(4) (2013) 409416. DOI: http://doi.org/.1021/ed300181t.

[5] M. Ratcliffe, ASE Guide to Secondary Science Education, Hatfield Publisher,1998.

[6] K. Ross. L. Lakin. P. Callaghan, Teaching Secondary Science: Constructing Meaning and Developing Understanding, David Fulton Publishers, 2002.

[7] A. Hofstein, V.N. Lunetta, The Laboratory in Science Education: Foundations for The TwentyFirst Century, Science Education 88(1) (2003) 28-54. DOI: https://doi.org/10.1002/sce.10106

[8] F.L. Forcino, The Importance of A Laboratory Section on Student Learning Outcomes in A University Introductory Earth Science Course, Journal of Geoscience Education 61(2) (2013) 213-221. DOI: https://doi.org/10.5408/12-412.1

[9] B. Boris. S. Natalia. P. Irina. T. Albina. B. Belysheva, Effect of Virtual Analytical Chemistry Laboratory on Enhancing Student 
Research Skills and Practices 25(1) (2017) 1-20. DOI: https://doi.org/10.25304/rlt.v25.1968

[10] I.A. D Astuti, S. Handayani, Penggunaan Virtual Laboratory Berbasis PhET Simulation untuk Menentukan Konstanta Wien, Jurnal Penelitian Pembelajaran Fisika 9(2) (2018) 66-72. DOI: https://doi.org/10.26877/jp2f.v9i2.2487

[11] E. Ismanto, M. Novalia, P.B. Herlandy, Pemanfaatan Smartphone Android Sebagai Media Pembelajaran Bagi Guru SMA Negeri 2 Kota Pekanbaru, Jurnal Pengabdian Untukmu Negeri 1(1) (2017) 42-45. DOI; https://doi.org/10.37859/jpumri.v1i1.33

[12] A. Putri. Syakbaniah, Yulkifli, Pengembangan Virtual Laboratory pada Materi Kinetika dengan Analisis Vektor dalam Pembelajaran Fisika di Kelas XI SMA, Pillar of Physics Education 1(1) (2013) 23-29. DOI: http://dx.doi.org/10.24036/486171074

[13] R.K. Scheckler, Virtual Labs, A Substitute for Traditional Labs?, International Journal of Developmental Biology 47(3) (2003) 231-236. DOI: https://doi.org/10.1387/ijdb.12705675

[14] D-K. Al Hasan, The Impact of Virtual Laboratories on Academic Achievement and Learning Motivation in The Students of Sudanese Secondary School, Journal of Engineering Education Transformations 4(9) (2016) 464-483. DOI: 10.16920/jeet/2016/v30i1/97425

[15] W. Kurniawan, J. Jufrida, F.R. Basuki, R. Ariani, O. Fitaloka, Virtual Laboratory Based Guided Inquiry: Viscosity Exsperiments, Jurnal Ilmu Pendidikan Fisika 4(2) (2019) 91-98. DOI: http://dx.doi.org/10.26737/jipf.v4i2.1069

[16] A. Gunawan, Harjono, H. Sahidu, Virtual Laboratory of Electricity Concept to Improve Prospective Physics Teachers Creativity, Jurnal Pendidikan Fisika Indonesia 13(2) (2017) 102111.

DOI: https://doi.org/10.15294/jpfi.v13i2.10152

[17] B. Kollöffe, T. Dejong, Conceptual Understanding of Electrical Circuits in Secondary Vocational Engineering Education: Combining Traditional Instruction with Inquiry Learning in A Virtual Lab, Journal of Engineering Education 102(3) (2013) 375-392. DOI: https://doi.org/10.1002/jee.20022
[18] Q. Suleman, H. Ishtiaq, M. Naseeruddin, Role of Instructional Technology in Enhancing Student' Educational Attainment in General Science at Elementary Level in Karak District Pakistan, Journal of Sociological Research 4(1) (2013) 8398. DOI: https://doi.org/10.5296/jsr.v4i1.3190

[19] H. Aktamis, E. Higde, B Ozden, Effects of The Inquiry Based Learning Method on Students' Achievement, Science Process Skills and Attitudes towards Science: A Meta-Analysis Science. Journal of Turkish Science Education 13(4) (2016) 248-261. DOI: https://doi: 10.12973/tused.10183a)

[20] J. Wang, D. Guo, M. Jou, A Study on The Effects of Model Based Inquiry Pedagogy on Students' Inquiry Skills in A Virtual Physics Lab, Journal Computers in Human Behavior 49(12) (2015) 658-669. DOI: http://dx.doi.org/10.1016/j.chb.2015.01.043 